\title{
Review of fungal chitosan: past, present and perspectives in Brazil
}

\author{
Anabelle Camarotti de Lima Batista ${ }^{1,2 *}$, Francisco Ernesto de Souza Neto ${ }^{2}$ and Weslley de Souza Paiva ${ }^{2}$ \\ 'Departamento de Agricultura - DA, Centro de Ciências Humanas, Sociais e Agrárias - CCHSA, \\ Universidade Federal da Paraiba - UFPB, Bananeiras, PB, Brasil \\ ${ }^{2}$ Programa de Pós-graduação em Ciência e Engenharia de Materiais - PPGCEM, Universidade Federal \\ Rural do Semi-Árido - UFERSA, Mossoró, RN, Brasil \\ *bellecamarotti@gmail.com
}

\begin{abstract}
Fungal chitosan is a polymer that has been discussed and studied since 1859 in the world with great advances occurring over the years. Due to its global importance, this review aims to expose the history of the production and application of fungal chitosan in Brazil. Data collection was done at the Scielo, Sciencedirect and Pubmed databases, considering the period of the last 50 years. The inclusion criteria were articles on pure or associated chitosan and, in particular, fungal chitosan produced or applied by Brazilian research groups. At the end of the review, it was noticed a fungal chitosan very studied in different continents, and in Brazil is still used in specific and small groups. With the present work, it is expected that the diffusion of the studies will be accelerated and that potential research groups for fungal chitosan may grow through interaction with the existing ones.
\end{abstract}

Keywords: fungal chitosan, biopolymer, biomedical application, biotechnology industries.

\section{Introduction}

The production of chitosan by the process of chemical deacetylation from the shell of crustaceans is financially advantageous for some industries. In Brazil, this process produces, in general, medium molecular weight chitosan and $\sim 80 \%$ deacetylation degree. Chitosan with this standard is marketed nationally by the company Polymar Science and Nutrition S.A, located in Ceará and classified as food by the Ministry of Health. It is marketed only with weight reducer and cholesterol. This marketing line released by the Brazilian Ministry of Health takes into account literature reports on the purity of preparations containing chitosan obtained from $\alpha$-chitin, which does not always meet the standards required in the areas related to pharmacy, medicine and food ${ }^{[1-4]}$.

In order for the chitosan obtained from $\alpha$-chitin to be used by the pharmaceutical, medical and food industries, it is necessary that several specific purification processes need to be done in order to correctly remove traces of proteins and pigments ${ }^{[5,6]}$. These processes raise production costs and decrease yield. These processes often depolymerize the resulting chitosan in a random manner ${ }^{[7,8]}$, in addition to producing many chemical pollutants that are difficult to reuse or discard. This fact does not occur with chitosan originating from fungi, leaving its production potentially profitable financially.

Another argument is the difficulty of adapting a standard in the production of chitosan from the crustacean shell inside an industrial plant, in order to maintain the physicochemical properties of the biopolymer ${ }^{[9]}$.

With this in mind, the microbiological production of chitosan from submerged fungi cultures has the advantage of being easier to set a standard for desirable physicochemical characteristics and to implement in an industrial plant because it has the advantage of yielding greater production in smaller areas ${ }^{[10-14]}$. As well as contributing to the reduction of environmental waste generated by the production of chitosan from the deacetylation of $\alpha$-chitin.

Based on its biotechnological potential and global importance, this review intends to organize and catalog the researchers and research groups that work directly or indirectly with fungal chitosan in Brazil with a view to facilitating the exchange of knowledge between the groups. In addition to promoting the dissemination of what has been done about the production and application in the last 33 years, since it was published pioneering work in Brazil on the analysis of the cell wall of fungi belonging to the class of Zygomycetes, Mucorales order by Campos-Takaki et al. ${ }^{[15]}$.

\section{Fungal Chitosan}

The fungal cell wall is mainly composed of a network of interconnected molecules consisting of proteins, glucans, chitin, chitosan, lipid and polyphosphates which may have the quantity and/or quality changed due to environmental conditions and intrinsic characteristics of their own species ${ }^{[15,16]}$. Among the compounds found in the cell wall of fungi, chitosan stands out for being associated to increased 
integrity, favoring protection against high temperatures and cell inhibitors to which the fungal strain may be subjected ${ }^{[17-19]}$.

The production of chitosan in the cell wall of fungi occurs due to the activity of the chitin deacetylase enzyme (EC 3.5.1.41) on the chitin residues present in the cell wall itself. This synthesis was first described in 1974 by Araki and Ito in Mucor rouxii (Zygomycetes) showing that about $14 \%$ of chitin deacetylase directly involved in the natural synthesis of chitosan in fungi is present and associated with particles of cell fractions, $49 \%$ is associated with a soluble fraction of the supernatant, and about $37 \%$ is extracellular ${ }^{[20]}$. Complementing the route of synthesis of chitosan, Davis and Bartnicki-Garcia ${ }^{[21]}$ found strong indications that the activity of the chitin deacetylase is highly efficient on residues from a growing chain of chitin, and has low efficiency in the preformed chitin molecule suggesting that changes in the culture medium in which the fungi grow can directly influence the production of chitosan. In the following years, new researchers studied the line of analysis of the wall and the confirmation of the presence of chitosan in different fungal species ${ }^{[22-24]}$.

\section{History of Fungal Chitosan in the World}

The first chitin isolation reports are from 1811, when the French professor Henri Braconnot conducted tests with isolates from Agaricus volvaceus, A. acris, A. Cantarellus, A. piperatus, Hydnum repandum, $H$. hybridum and Boletus viscidus and obtained a crude extract formed by chitin-glucan complex, lacking proteins and pigments and presenting acetyl groups, which he called "fungine". Odier, in 1823 , named "chitin" the insoluble substance that he isolated from the exoskeleton of insects. Odier also realized this same substance could be found in the shell of crabs, and speculated that this could be a basic material present in the exoskeleton of insects ${ }^{[25]}$.

In the nineteenth century, the researchers Odier described the isolation of chitin from the cuticle of insects as well as from mushrooms. This process was done by performing multiple treatments with a concentrated sodium hydroxide solution. With this report in mind, it is reasonable to believe that the material which resulted from such process had been chitosan, because when chitin is exposed to concentrated alkaline media, the deacetylation of this biopolymer is stimulated, and chitosan is obtained ${ }^{[26]}$.

The description of the presence of an amine grouping at carbon 2 of the residues, determining characteristic of the formation of chitosan, was initially done by Rouget in 1859 , however the name "chitosan" was proposed by Hoppe-Seyler in 1984 ${ }^{[27]}$.

Since its description and designation, chitosan was for many years the subject of basic research only. However, this scenario has been changing since the mid-1970s, when its vast potential in different applications was noted (Table 1).

\section{Fungal Chitosan in the Industry}

Companies that realized its marketable potential have used the fungal chitosan in industries worldwide. These companies have diverse uses for this biopolymer, more specifically in the medical field. Among the companies that promote bioproducts produced with fungal chitosan, we have:

Table 1. Overview of studies on the potential of chitosan in different applications regardless of the method used to obtain it and its physicochemical characteristics, from 1970 until now.

\begin{tabular}{|c|c|c|}
\hline Period & Application potential & References \\
\hline 1970-79 & $\begin{array}{l}\text { Enzyme immobilization; } \\
\text { Healing activity }\end{array}$ & $\begin{array}{l}\text { Muzzarelli }{ }^{[28,29]} \text {, Balassa }{ }^{30]} \text {, Leuba and Widmer }{ }^{31,32]} \text {, Kasumi et al. }{ }^{[33} \text {, } \\
\text { Bissett and Sternberg }{ }^{[34]}\end{array}$ \\
\hline 1980-89 & Treatment of industrial residues; Heavy metals biosorption & Muzzarelli et al. ${ }^{[35,36]}$, Muzzarelli ${ }^{[37]}$ \\
\hline 1990-99 & $\begin{array}{l}\text { Effluent treatment; } \\
\text { Enzyme immobilization; } \\
\text { Film production }\end{array}$ & $\begin{array}{l}\text { Muzzarelli et al. }{ }^{[38]} \text {, Muzzarelli }{ }^{[39]} \text {, Dobetti and Delben }{ }^{[40]} \text {, Hoagland } \\
\text { and Parris }{ }^{[41]}\end{array}$ \\
\hline 2000-09 & $\begin{array}{l}\text { Degradation of dyestuff; } \\
\text { Enzyme immobilization; } \\
\text { Biosorption and adsorption of Heavy metals; } \\
\text { Food conservation; } \\
\text { Medical application }\end{array}$ & $\begin{array}{l}\text { Jin and } \mathrm{Bai}^{[42]} \text {, Amorim et al. }{ }^{[43]} \text {, Chiou et al. }{ }^{[44]} \text {, Franco et al. }{ }^{[45]} \text {, Jeon } \\
\text { and Ha Park }{ }^{[46]} \text {, Rungsardthong }{ }^{[47]} \text {, Zhao et al. }{ }^{[48]} \text {, Crini and Badot }{ }^{[49]} \text {, } \\
\text { Baroni et al. }{ }^{[50]} \text {, Perioli et al. } .^{[51]} \text {, Cheung et al. } .^{[52]}\end{array}$ \\
\hline 2010-now & $\begin{array}{l}\text { Cosmetics; } \\
\text { Medical application; } \\
\text { Food conservation; } \\
\text { Biocapsules production; } \\
\text { Effluent treatment; } \\
\text { Adsorption of heavy metals } \\
\text { Antiparasitic }\end{array}$ & 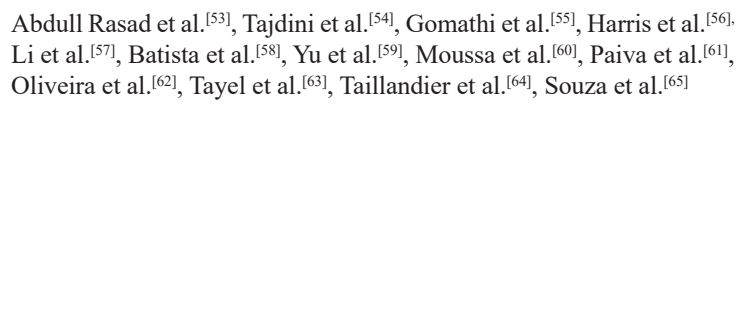 \\
\hline
\end{tabular}


- Kitozyme: Belgian company pioneer in the production of highly pure non-animal chitosan. It holds some unique patents on the production processes of polymers, such as chitosan. Its products are KiOnutrime-CsG, which absorbs of fat in the human organism; KiObind, which is a combination of the previous with vitamin $\mathrm{C}$; and KioCardio, which decreases cholesterol levels ${ }^{[66]}$;

- InvivoGen: American company that uses chitosan as a vaccine adjuvant to promote protein adsorption on mucosal surfaces. Their commercial product is called Chitosan VaccGrade ${ }^{[67]}$;

- nbiose: Belgian biotechnology company focused on providing carbohydrates with added value to their clients, aiming applications in various fields, such as nutrition, biomedical, pre-biotics, etc. They make use of a technology that yields good chitosan production using fermentation techniques. This allows reasonable costs and high productive yield ${ }^{[68]}$.

\section{History of Fungal Chitosan in Brazil}

\subsection{Past}

The pioneering studies to identify and quantify fungal chitosan in Brazil were the works published by Galba Maria Campos-Takaki et al. ${ }^{[15]}$. In 1983, this group analyzed the cell wall of fungi, from the Zygomycetes class and Mucorales order, using cytochemical, ultrastructural and X-ray microanalysis techniques. In the said work, they confirmed the presence of chitosan in the cell wall of those fungi and that noted that the polysaccharide values vary from $26-28 \%$ of dry weight of the species analyzed.

From 2001, Amorim and colleagues, obtained for the first time chitosan from fungi, using strains of Mucorales. In addition, one of their results was the finding of a degree of $\mathrm{N}$-acetylation of $49 \%$ for Mucor recemosus strain and $20 \%$ for Cunnigamella elegans, and quantities of D-glucosamine of $48 \%$ and $90 \%$, respectively ${ }^{[10]}$.

Continuing the research on chitosan extracted from strains of the Mucorales order, Amorim et al., (2003) obtained chitosan from Syncephalastrum racemosum with degree of deacetylation (DD) of $88.99 \%$, and performed lipase immobilization using support film made from the chitosan they obtained ${ }^{[43]}$. The immobilization of the lipase with this biofilm reduced the catalytic activity of the enzyme in about $47 \%$. These are similar results to those collected from studies that used the immobilization film made from crustacean chitosan, which demonstrates the potential of fungal chitosan in biotechnological production against similar products that are already commercialized for different applications, such as crustacean chitosan ${ }^{[40,42,44]}$.

In 2004, Franco et al. ${ }^{[45]}$ continued Brazilian research using fungal chitosan in bonds with metals, such as iron and copper. The work intended to use this polysaccharide as a bioremedy agent, assisting in the elimination of heavy metals from the environment. The experiment demonstrated good biotechnological potential for fungal chitosan obtained from Cunninghamella elegans in copper adsorption.

Having potential producers in mind and always comparing their samples to chitosan produced from chitin obtained from the shell of crustaceans. The same research group, in 2005, published a study that aimed to assess the production yield from the extraction of chitin and chitosan from a strain of Cunninghamella elegans (IFM 46109) when compared to other strains of the Zygomycetes class, and to the chitosan extracted from the shell of crustaceans. As a result, they demonstrate that fungal chitosan compares to chitosan derived from chitin obtained from crustaceans as to their physicochemical characteristics ${ }^{[69]}$.

Stamford et al, 2007 conducted tests on various culture media and different incubation periods to optimize the production of chitosan from the fungus Cunninghamella elegans, they obtained chitosan with a degree of deacetylation of $85 \%{ }^{[70]}$.

In 2008, Fai et al. ${ }^{[71]}$ expanded studies regarding chitosan by applying it as an additive to better food conservation over time, proving its efficiency and turning it into a promising molecule for large-scale use in the food industry.

In 2009, Bento et al. ${ }^{[72]}$ investigated the production of chitosan from the fungus Mucor rouxxi UCP 064, obtaining deacetylation degree of $85 \%$ and the highest yield of the polymer with only 48 hours of cultivation. The same study applied the chitosan they obtained in an antimicrobial test against Listeria monocytogenes, finding good results on the inhibition of this microorganism. In the same year, Bento et al. ${ }^{[73]}$ applied chitosan as an inhibitor of Listeria monocytogenes in meat products, and had satisfactory results on the inhibition of this microorganism.

\subsection{Present}

At the present moment, the Mucorales order Zygomycetes class, is the most representative and studied in the biotechnology field for containing most species that produce biocompounds of great commercial interest (Table 2).

Among many compounds of interest, chitosan should be highlighted, since these species have large quantities of this biopolymer in their cell wall when they are in their vegetative form $^{[21,83]}$.

Currently the work on fungal chitosan is divided into production, where studies concern more profitable and sustainable ways of obtaining this biopolymer; and application, in which one observes patents and marketable potential for this biotechnological product of international acceptance.

\subsection{Production}

In the nineteenth century, the scientist White et al. ${ }^{[84]}$ developed a methodology that allowed the isolation of chitosan from fungal mycelium. From this study, several other scientists have begun to develop adaptations to seek improving the process efficiency ${ }^{[24,85,86]}$. Based on these studies, the scientist HU and colleages (1999), in the late twentieth century, developed an extraction protocol that is currently one of the most used in experiments with fungal chitosan. This protocol describes each step to be performed from cultivation period to specific $\mathrm{pH}$ values, which are essential for the success of the extraction ${ }^{[87]}$.

Using the extraction process described by $\mathrm{Hu}$ et al. ${ }^{[87]}$, many Brazilian researchers aim to acquire higher yield of fungal chitosan as well as decrease production costs in order 
Table 2. Biopolymer production by species from the Mucorales order as depend of the cultivation conditions. The cultivation conditions interfere directly of the better biopolymer production.

\begin{tabular}{|c|c|c|}
\hline Species & Biopolymer & Reference \\
\hline Syncephalastrum sp. & $\begin{array}{l}\alpha \text {-amylase; } \\
\text { chitosan; }\end{array}$ & Yu et al. ${ }^{[59]}$, Batista et al. ${ }^{[74]}$, Freitas et al. ${ }^{[75]}$ \\
\hline Cunninghamella sp. & Chitosan & Oliveira et al. ${ }^{[62]}$, Tayel et al. ${ }^{[63]}$ \\
\hline Rhizopus sp. & $\begin{array}{l}\text { chitin; } \\
\text { chitosan }\end{array}$ & Cardoso et al. ${ }^{[76]}$, Berger et al. ${ }^{[77]}$ \\
\hline Rhizopus stolonifer & Chitosan & Paiva et al. ${ }^{[78]}$ \\
\hline Mucorspp. & $\begin{array}{c}\text { enzyme production; } \\
\text { chitosan }\end{array}$ & Bento et al..$^{[79]}$, Fai et al. ${ }^{[80]}$, Souza et al. ${ }^{[81]}$ \\
\hline Fusarium sp. & Chitosan & Berger et al. ${ }^{[82]}$ \\
\hline
\end{tabular}

to compete commercially with chitosan obtained from chitin from crustacean's shell.

Cardoso et al. ${ }^{[76]}$ performed the extraction of fungal chitosan by media comprised of by-products of the food agribusiness and were able to obtain $29.30 \mathrm{mg}$ of chitosan per gram of dry mass of Rhizopus arrhizus; and Berger et al. ${ }^{[7]}$ obtained $57.82 \mathrm{mg}$ of chitosan per gram of dry mass of Cunnigamella ellegans UCP / WFCC 0542. Batista et al. ${ }^{[88]}$, managed to increase yield working with a medium composed of the by-product of shrimp industry, reaching up to $89.95 \mathrm{mg}$ of chitosan per $1 \mathrm{~g}$ of biomass of Rhyzopus spp.

The values aforementioned, when compared to animal chitosan, obtained from the chitin extracted from the shell of crustaceans, still reflect lower yield. However, when taking into account the physicochemical characteristics, the ease of obtaining, the low cost purification and the little chemical waste generated by the production of fungal chitosan when compared to animal chitosan production, this difference becomes minimal ${ }^{[89,90]}$.

Based on the synthesis path of chitosan in fungi, many researchers have shown that several factors can affect the production of this biopolymer by submerged fungi culture. These factors have also been described as important for the production and manipulation of physicochemical characteristics of chitosan according to the literature ${ }^{[1-95]}$.

\subsection{Some characterizations and applications}

In Brazil, fungal chitosan has already been tested in different applications depending on its physicochemical characteristics. The most used characterizations in chitosan studies were infrared spectroscopy and molecular weight. The infrared technique is based on the Fourier Transform Infrared Spectroscopy, FT-IR, to obtain the degree of deacetylation as a function of Equation 1:

$$
\operatorname{DD}(\%)=100-\left[\left(\frac{A_{1655}}{A_{3450}}\right) x \frac{100}{1.33}\right]
$$

where: $\mathrm{A}_{1655}$ is the absorbance at $1655 \mathrm{~cm}^{-1}$ of the amide I band, $\mathrm{A}_{3450}$ is the absorbance at $3450 \mathrm{~cm}^{-1}$ of the hydroxyl band and 1.33 is the value of the $\mathrm{A}_{1655} / \mathrm{A}_{3450}$ proportion for a completely acetylated chitosan. Adapted from Martínez-Camacho et al. ${ }^{[96]}$ and Khan et al. ${ }^{[97]}$.
The molecular weight characterization is closely related to the intrinsic viscosity, where chitosan solutions are passed through Ubbelohde capillary in a water bath and the determination of the molecular weight occurs as a function of the Mark-Houwink-Sakurada Equation 2:

$$
[\eta]=k M V^{a}
$$

where $[\eta]$ is the intrinsic viscosity, MV is the average viscometric molecular weight and both " $\kappa$ " and "a" are empirical constants that depend of the polymer nature, the solvent and the temperature. " $\kappa$ " and "a" values were $3.04 \times 10^{-5}$ and 1.26 , respectively adapted from Martínez-Camacho et al. ${ }^{[96]}$ and Rinaudo et al. ${ }^{[98]}$.

Other techniques that are used to characterize fungal chitosan are thermogravimetry, where it is possible to analyze if there are contaminants in the sample; Scanning electron microscopy, which demonstrates the structure of the polymer; and X-ray diffraction, which indicates the crystallinity of the material. These characteristics are very important for choosing a good polymer for an efficient application ${ }^{[43,60,62]}$.

\subsubsection{Antimicrobial activity application}

Currently, a major concern in the use of antibiotics is the accumulation of synthetic substances in the body, in addition to the high rate in which the selection of microorganisms resistant to commonly known drugs increases. Therefore, some groups of Brazilian researchers conducted studies in which they used fungal chitosan as a bactericidal agent ${ }^{[62,65]}$.

For the antimicrobial action three mechanisms are proposed: (1) related to the formation of polyelectrolytic complexes, because chitosan has positive charges present in its chain, due to its amine group, that bind selectively to the cell surface of the microorganisms, changing its activity, Permeability of the membrane and reducing the cellular components, resulting, then, in the inhibition or cell death; (2) chitosan acts as a chelating agent, binding to the ions that are necessary for the functioning of certain enzymes; (3) when chitosan is also low in molecular weight, being able to insert into the nucleus of the microbial cell, interacting with the DNA, and interfering with the activities of messenger RNA, consequently affecting protein synthesis ${ }^{[54,60,63,96]}$.

In order for the antimicrobial action to occur, some studies show a connection with the degree of deacetylation above $75 \%$; And molecular weight, that the lower, the greater the action of chitosan against microorganisms ${ }^{[43,45,54,60,62]}$. 
Paiva and colleagues, in 2014, tested the chitosan extracted from Cunninghamella elegans, as an antibacterial agent against Escherichia coli and Staphylococcus aureus, the study was successful in inhibiting bacteria in all times tested, proving the effectiveness of chitosan as an antibacterial agent ${ }^{[61]}$.

In addition to the bactericidal activity, fungal chitosan may also have fungicidal activity. Oliveira et al. ${ }^{[62]}$ extracted chitosan from Cunninghamella elegans to used as coating for fruit (grape - Vitis labrusca L.) and prevented the growth of pathogenic fungi. In this work, a chitosan was used in film form with $81 \%$ degree of deacetylation and average molecular weight. For this application in the form of film, in particular, it was pointed out that if the polymer under study were of low molecular weight, there would be a decrease in the tensile strength and permeability of the film. Within this experiment, they also found that such alternative coating did not influence the sensory conditions of this fruit.

\subsubsection{Application of chitosan as biofertilizers}

Stamford et al (2015) published a patent in Brazil describing the biofertilizer and bioprotector abilities of fungal chitosan. This chitosan was produced from mixed biofertilizer (phosphate and potassium rocks, along with sulfur and an inoculum of acidithiobacillus bacteria; organic matter inoculated with diazotrophs free life bacteria; and fungi that produce chitin and chitosan). This production was carried out in a purely biological way, and resulted in a product with a high fertilizer and protection effect against phytopathogenic microorganisms present in the soil, without the need to use external energy sources ${ }^{[99]}$.

\subsubsection{Enzyme immobilization}

The enzyme immobilization technique is much valued in cosmetics, food and pharmaceutical industries. Having this in mind, Amorim et al. ${ }^{[43]}$ used fungal chitosan as a film for perform enzyme immobilization. In their experiment, the degree of deacetylation of fungal chitosan was $88.9 \%$. This characteristic was thought due to chitosan to provide as reactive points a smaller amount of acetamide clusters. In this way, there is a decrease in the density of the chitosan molecule and favoring its function as a support for the immobilization of enzymes. They aimed to immobilize an enzyme called lipase and watch its time of activity. As a result, they found $47 \%$ of initial catalytic activity after four reaction cycles. Therefore, these results are as efficient as those found in studies using animal chitosan (obtained from crustaceans shells).

\section{Prospects}

After its discovery, chitosan has become a source of numerous studies around the world due to its versatility of use. Initially, the most commonly used type of chitosan was that obtained from the shell of shrimp, however, with the discovery of the presence of chitosan in the cell wall of fungi, which is extracted with less production of waste during purification and no presence of allergenic substances, the fungal or biotechnological chitosan gained ground in worldwide research groups ${ }^{[100]}$.
In Brazil, the first reports date back to the early 80's, with the research group of Professor Dr. Galba Maria de Campos-Takaki. After this first study, the others that followed tried to understand the structure of the fungus, how this chitosan behaves under different conditions, alternative culture media for growth of fungus and measuring the chitosan production, as well as physicochemical characterizations of this chitosan using techniques such as X-ray, infrared, thermogravimetry, zeta pontencial and others ${ }^{[15]}$.

Currently, studies with fungal chitosan in Brazil seek a future biomedical application for this polymer. This can be in helping the body accept implants, such as dental, muscle or bone; using chitosan membranes to help with burn victims, establishing a relationship between the polymer and its reparative action on biological tissues; and in the antimicrobial activity of this polymer, helping to maintain aseptic conditions in hospital equipment.

The versatility of this polymer has also been found effective in the food engineering area, where research is focused on the production of biofilms and membranes that protect food from microorganisms, increasing its shelf-life and reducing financial losses due to contamination ${ }^{[59,63,77,101,102]}$.

Another way that fungal chitosan is being used in Brazil is in the material engineering field, where the polymer is being used as an insulating material to composites, resulting in decrease of plastic material, thus avoiding the serious environmental damage that the plastic accumulation causes in the environment.

Concerning the companies in this sector, Brazil is still taking regular steps when compared to the reality of Europe and the United States. Even presenting characteristics and qualified personnel for the development of new technologies. What we can observe from the groups involved in this area are robust visions that contribute to making Brazil a leading producer of fungal chitosan for any feasible purpose.

For this, further studies concerning fungal chitosan are relevant in order to be sure that its use is feasible and safe for humans. Even though there is some resistance from the industry to this polymer obtained from fungi due to its lower yield when compared to chitosan of animal origin, it is important to note that the cost of purification and the amount of waste generated are much lower. These facts gives the fungal chitosan a prominent place in scientific research in Brazil, as well as in the world.

\section{Conclusion}

Given the knowledge acquired during this work, we see that the use of fungal chitosan in Brazil needs to be further explored. To date, Brazilian scientists have cataloged different biological activities of fungal chitosan. These studies, even if they are still on bench scale and with few deposited patents, are important because they demonstrate the biotechnological potential of some groups operating in the Brazilian Northeast, an area still with little financial investment for the research when compared to the Southeast region.

In the world fungal chitosan has already been reported for different purposes and has already been used in different patented formulations. In Brazil, there are still studies of production and small applications that normally do not 
transgress the academic area. With the dissemination of the papers and exposition of the research groups it is expected that new agreements will be set up and that agreements with industrial sectors be signed for the purpose of patents and commercial projection of fungal chitosan, as it happens in Europe.

\section{Acknowledgements}

To doctoral program of the Northeast Biotechnology Network - RENORBIO; Center for Research in Environmental Sciences - NPCIAMB, Catholic University of Pernambuco; Federal Rural University of the Semi Arid; $\mathrm{CNPq}$ and CAPES for financial support.

\section{References}

1. Khor, E., \& Lim, L. Y. (2003). Implantable applications of chitin and chitosan. Biomaterials, 24(13), 2339-2349. http:// dx.doi.org/10.1016/S0142-9612(03)00026-7. PMid:12699672.

2. Campana-Filho, S. P., Britto, D., Curti, E., Abreu, F. R., Cardoso, M. B., Battisti, M. V., Sim, P. C., Goy, R. C., Signini, R., \& Lavall, R. L. (2007). Extração, estruturas e propriedades de alfa- e beta-quitina. Química Nova, 30(3), 644-650. http:// dx.doi.org/10.1590/S0100-40422007000300026.

3. Queiroz, M. F., Melo, K. R. T., Sabry, D. A., Sassaki, G. L., \& Rocha, H. A. O. (2014). Does the use of chitosan contribute to oxalate kidney stone formation? Marine Drugs, 13(1), 141-158. http://dx.doi.org/10.3390/md13010141. PMid:25551781.

4. Naghdi, M., Zamani, A., \& Karimi, K. (2014). A sulfuric-lactic acid process for efficient purification of fungal chitosan with intact molecular weight. International Journal of Biological Macromolecules, 63, 158-162. http://dx.doi.org/10.1016/j. ijbiomac.2013.10.042. PMid:24211428.

5. Rinaudo, M. (2006). Chitin and chitosan: properties and applications. Progress in Polymer Science, 31(7), 603-632. http://dx.doi.org/10.1016/j.progpolymsci.2006.06.001.

6. Struszczyk, M. H. (2002). Chitin and chitosan - part I. Properties and production, Warsaw, Poland. Polimery, 1(5), 316-325. Retrieved in 2016, July 15, from http://en.www.ichp. $\mathrm{pl} /$ Chitin-and-Chitosan-Part-I-Properties-and-production

7. Choi, W.-S., Ahn, K.-J., Lee, D.-W., Byun, M.-W., \& Park, H.-J. (2002). Preparation of chitosan oligomers by irradiation. Polymer Degradation \& Stability, 78(3), 533-538. http://dx.doi. org/10.1016/S0141-3910(02)00226-4.

8. Yue, W. (2014). Prevention of browning of depolymerized chitosan obtained by gamma irradiation. Carbohydrate Polymers, 101, 857-863. http://dx.doi.org/10.1016/j.carbpol.2013.10.011. PMid:24299848.

9. Tayel, A. A., Moussa, S. H., El-Tras, W. F., Knittel, D., Opwis, K., \& Schollmeyer, E. (2010). Anticandidal action of fungal chitosan against Candida albicans. International Journal of Biological Macromolecules, 47(4), 454-457. http://dx.doi. org/10.1016/j.ijbiomac.2010.06.011. PMid:20603144

10. Amorim, R. V. S., Souza, W., Fukushima, K., \& Campos-Takaki, G. M. (2001). Faster chitosan production by Mucorelean strains in submerged culture. Brazilian Journal of Microbiology, 32(1), 20-23. http://dx.doi.org/10.1590/S1517-83822001000100005.

11. Amorim, R. V. S., Ledingham, W. M., Kennedy, J. F., \& Campos-Takaki, G. M. (2006). Chitosan from Syncephalastrum racemosum using sugar cane substrates as inexpensive carbon sources. Food Biotechnology, 20(1), 43-53. http://dx.doi. org/10.1080/08905430500524028.

12. Feng, Y. L., Li, W. Q., Wu, X. Q., Cheng, J. W., \& Ma, S. Y. (2010). Statistical optimization of media for mycelial growth and exo-polysaccharide production by Lentinus edodes and a kinetic model study of two growth morphologies. Biochemical Engineering Journal, 49(1), 104-112. http://dx.doi.org/10.1016/j. bej.2009.12.002.

13. Liu, R. S., Li, D. S., Li, H. M., \& Tang, Y. J. (2008). Response surface modeling the significance of nitrogen source on the cell growth and Tuber polysaccharides production by submerged cultivation of Chinese truffle Tuber sinense. Process Biochemistry, 43(8), 868-876. http://dx.doi.org/10.1016/j. procbio.2008.04.009.

14. Pokhrel, C. P., \& Ohga, S. (2007). Submerged culture conditions for mycelial yield and polysaccharides production by Lyophyllum decastes. Food Chemistry, 105(2), 641-646. http://dx.doi.org/10.1016/j.foodchem.2007.04.033.

15. Campos-Takaki, G. M., Beakes, G. W., \& Dietrich, S. M. (1983). Electron microscopic X-ray microprobe and cytochemical study of isolated cell walls of mucoralean fungi. Transactions of the British Mycological Society, 80(3), 536-541. http://dx.doi. org/10.1016/S0007-1536(83)80053-9.

16. Ruiz-Herrera, J. (2012). Fungal cell wall: estructure, synthesis, and assembly. In J. Ruiz-Herrera (Ed.), Current topics in medical mycology (Vol. 3, pp. 168-217). New York: Springer. http:// dx.doi.org/10.1201/b11873.

17. Adams, D. J. (2004). Fungal cell wall chitinases and glucanases. Microbiology, 150(1), 2029-2035. http://dx.doi.org/10.1099/ mic.0.26980-0. PMid:15256547.

18. Baker, L. G., Specht, C. A., Donlin, M. J., \& Lodge, J. K. (2007). Chitosan, the Deacetylated form of chitin, is necessary for cell wall integrity in Cryptococcus neoformans. Eukaryotic Cell, 6(5), 855-867. http://dx.doi.org/10.1128/EC.00399-06. PMid:17400891.

19. Banks, I. R., Specht, C. A., Donlin, M. J., Gerik, K. J., Levitz, S. M., \& Lodge, J. K. (2005). A chitin synthase and its regulator protein are critical for chitosan production and growth of the fungal pathogen Cryptococcus neoformans. Eukaryotic Cell, 4(11), 1902-1912. http://dx.doi.org/10.1128/EC.4.11.19021912.2005. PMid:16278457.

20. Araki, Y., \& Ito, E. (1974). A pathway of chitosan formation in Mucor rouxii: enzymatic deacetylation of chitin. Biochemical and Biophysical Research Communications, 56(3), 669-675. http:// dx.doi.org/10.1016/0006-291X(74)90657-3. PMid:4826874.

21. Davis, L. L., \& Bartnicki-Garcia, S. (1984). Chitosan synthesis by the tandem action of chitin synthetase and chitin deacetylase from Mucor rouxii. Biochemistry, 23(6), 1065-1073. http:// dx.doi.org/10.1021/bi00301a005.

22. Kendra, D. F., Christian, D., \& Hadwiger, L. A. (1989). Chitosan oligomers from Fusarium solani/pea interactions, chitinase/ßglucanase digestion of sporelings and from fungal wall chitin actively inhibit fungal growth and enhance disease resistance. Physiological and Molecular Plant Pathology, 35(3), 215-230. http://dx.doi.org/10.1016/0885-5765(89)90052-0.

23. Sudarshan, N. R., Hoover, D. G., \& Knorr, D. (1992). Antibacterial action of chitosan. Food Biotechnology, 6(3), 257-272. http://dx.doi.org/10.1080/08905439209549838.

24. Synowiecki, J., \& Al-Khateeb, N. A. A. Q. (1997). Mycelia of Mucor rouxii as a source of chitin and chitosan. Food Chemistry, 60(4), 605-610. http://dx.doi.org/10.1016/S03088146(97)00039-3.

25. Braconnot, H. (1811). Sur la nature des champignons. Annales de Chimie Physique, 79, 265-304.

26. Odier, A. (1823). Mémoir sur la composition chimique des parties cornées des insectes. Mémoirs de la Societé d'Histoire Naturelle, 1, 29-42.

27. Hoppe-Seyler F. (1894). Ueber chitosan und zellulose. Germany: Ber. Deutsche Chemische Gesellschaft. 
28. Muzzarelli, R. A. A. (1973). Natural chelating polymers: alginic acid, chitin, and chitosan. Oxford: Pergamon Press.

29. Muzzarelli, R. A. A. (1976).Biochemical modifications of chitin. In H. R. Hepburn (Ed.), The insect integument (pp. 63-87). New York: Elsevier Scientific Publishing Company.

30. Balassa, L. L. (1975). US Patent No 3903268. Estados Unidos. Retrieved in 2016, July 15, from http://patft.uspto.gov/netacgi/ nph-Parser?Sect2=PTO1\&Sect2=HITOFF \&p=1\&u=/netahtml/ PTO/searchbool.html\&r=1\&f=G\&l=50\&d=PALL\&RefSrch= yes\&Query=PN/3903268

31. Leuba, J. L., \& Widmer, F. (1977). Immobilization of the $\beta$-galactosidase from Aspergillus niger on chitosan. Journal of Solid-Phase Biochemistry, 3(2), 257-271. http://dx.doi. org/10.1007/BF02996747.

32. Leuba, J. L., \& Widmer, F. (1979). Immobilization of proteinases on chitosan. Biotechnology Letters, 1(3), 109-114. http://dx.doi. org/10.1007/BF01386708.

33. Kasumi, T., Tsuji, M., Hayashi, K., \& Tsumura, N. (1977). Preparation and some properties of chitosan bounds enzymes. Agricultural and Biological Chemistry, 41(10), 1865-1872. http://dx.doi.org/10.1080/00021369.1977.10862778.

34. Bissett, F., \& Sternberg, D. (1978). Immobilization of Aspergillus beta-glucosidase on chitosan. Applied and Environmental Microbiology, 35(4), 750-755. PMid:25624.

35. Muzzarelli, R. A. A., Tanfani, F., Emanuelli, M., \& Mariotti, S. (1982). N-(carboxymethylidene) chitosans and n-(carboxymethyl)chitosans: novel chelating polyampholytes obtained from chitosan glyoxylate. Carbohydrate Research, 107(2), 199-214. http://dx.doi.org/10.1016/S0008-6215(00)80539-X.

36. Muzzarelli, R. A. A., Tanfani, F., \& Emanuelli, M. (1984). Chelating derivatives of chitosan obtained by reaction with ascorbic acid. Carbohydrate Polymers, 4(2), 137-151. http:// dx.doi.org/10.1016/0144-8617(84)90020-1.

37. Muzzarelli, R. A. A. (1985). Removal of uranium from solutions and brines by a derivative of chitosan and ascorbic acid. Carbohydrate Polymers, 5(2), 85-89. http://dx.doi. org/10.1016/0144-8617(85)90026-8.

38. Muzzarelli, R. A. A., Weckx, M., Filippini, O., \& Sigon, F. (1989). Removal of trace metal ions from industrial waters, nuclear effluents and drinking water, with the aid of cross-linked N-carboxymethyl chitosan. Carbohydrate Polymers, 11(4), 293-306. http://dx.doi.org/10.1016/0144-8617(89)90004-0.

39. Muzzarelli, R. A. A. (1990). Book review: methods in enzymology: lignin, pectin and chitin. Carbohydrate Polymers, 12(2), 242243. http://dx.doi.org/10.1016/0144-8617(90)90024-M.

40. Dobetti, L., \& Delben, F. (1992). Binding of metal cations by $\mathrm{N}$-carboxymethyl chitosans in water. Carbohydrate Polymers, 18(4), 273-282. http://dx.doi.org/10.1016/0144-8617(92)900925.

41. Hoagland, P. D., \& Parris, N. (1996). Chitosan/pectin laminated films. Journal of Agricultural and Food Chemistry, 44(7), 1915-1919. http://dx.doi.org/10.1021/jf950162s.

42. Jin, L., \& Bai, R. (2002). Mechanisms of lead adsorption on chitosan/PVA hydrogel beads. Langmuir, 18(25), 9765-9770. http://dx.doi.org/10.1021/la0259171.

43. Amorim, R. V. S., Melo, E. S., Carneiro-da-Cunha, M. G., Ledingham, W. M., \& Campos-Takaki, G. M. (2003). Chitosan from Syncephalastrum racemosum used as a film support for lípase immobilization. Bioresource Technology, 89(1), 35-39. http://dx.doi.org/10.1016/S0960-8524(03)00035-X. PMid: 12676498.

44. Chiou, M. S., Ho, P. Y., \& Li, H. Y. (2004). Adsorption of anionic dyes in acid solutions using chemically cross-linked chitosan beads. Dyes and Pigments, 60(1), 69-84. http://dx.doi. org/10.1016/S0143-7208(03)00140-2.
45. Franco, L. O., Maia, R. C. C., Porto, A. L. F., Messias, A. S., Fukushima, K., \& Campos-Takaki, G. M. (2004). Heavy metal biosorption by chitin and chitosan isolated from Cunninghamella elegans (IFM 46109). Brazilian Journal of Microbiology, 35(3), 243-247. http://dx.doi.org/10.1590/ S1517-83822004000200013.

46. Jeon, C., \& Ha Park, K. (2005). Adsorption and desorption characteristics of mercury (II) ions using aminated chitosan bead. Water Research, 39(16), 3938-3944. http://dx.doi. org/10.1016/j.watres.2005.07.020. PMid:16129473.

47. Rungsardthong, V., Wongvuttanakul, N., Kongpien, N., \& Chotiwaranon, P. (2006). Application of fungal chitosan for clarification of apple juice. Process Biochemistry, 41(3), 589593. http://dx.doi.org/10.1016/j.procbio.2005.08.003.

48. Zhao, F., Yu, B., Yue, Z., Wang, T., Wen, X., Liu, Z., \& Zhao, C. (2007). Preparation of porous chitosan gel beads for copper(II) ion adsorption. Journal of Hazardous Materials, 147(1-2), 67-73. http://dx.doi.org/10.1016/j.jhazmat.2006.12.045. PMid:17258856.

49. Crini, G., \& Badot, P. M. (2008). Application of chitosan, a natural aminopolysaccharide, for dye removal from aqueous solutions by adsorption processes using batch studies: a review of recent literature. Progress in Polymer Science, 33(4), 399447. http://dx.doi.org/10.1016/j.progpolymsci.2007.11.001.

50. Baroni, P., Vieira, R. S., Meneghetti, E., da Silva, M. G., \& Beppu, M. M. (2008). Evaluation of batch adsorption of chromium ions on natural and crosslinked chitosan membranes. Journal of Hazardous Materials, 152(3), 1155-1163. http:// dx.doi.org/10.1016/j.jhazmat.2007.07.099. PMid:17826905.

51. Perioli, L., Ambrogi, V., Pagano, C., Scuota, S., \& Rossi, C. (2009). FG90 chitosan as a new polymer for metronidazole mucoadhesive tablets for vaginal administration. International Journal of Pharmaceutics, 377(1-2), 120-127. http://dx.doi. org/10.1016/j.ijpharm.2009.05.016. PMid:19454304.

52. Cheung, W. H., Szeto, Y. S., \& Mckay, G. (2009). Enhancing the adsorption capacities of acid dyes by chitosan nano particles. Bioresource Technology, 100(3), 1143-1148. http:// dx.doi.org/10.1016/j.biortech.2008.07.071. PMid:18829305.

53. Abdull Rasad, M. S. B., Halim, A. S., Hashim, K., Rashid, A. H. A., Yusof, N., \& Shamsuddin, S. (2010). In vitro evaluation of novel chitosan derivatives sheet and paste cytocompatibility on human dermal fibroblasts. Carbohydrate Polymers, 79(4), 1094-1100. http://dx.doi.org/10.1016/j.carbpol.2009.10.048.

54. Tajdini, F., Amini, M. A., Nafissi-Varcheh, N., \& Faramarzi, M. A. (2010). Production, physiochemical and antimicrobial properties of fungal chitosan from Rhizomucor miehei and Mucor racemosus. International Journal of Biological Macromolecules, 47(2), 180-183. http://dx.doi.org/10.1016/j. ijbiomac.2010.05.002. PMid:20471417.

55. Gomathi, P., Ragupathy, D., Choi, J. H., Yeum, J. H., Lee, S. C., Kim, J. C., Lee, S. H., \& Ghim, H. D. (2011). Fabrication of novel chitosan nanofiber/gold nanoparticles composite towards improved performance for a cholesterol sensor. Sensors and Actuators. B, Chemical, 153(1), 44-49. http:// dx.doi.org/10.1016/j.snb.2010.10.005.

56. Harris, R., Lecumberri, E., Mateos-Aparicio, I., Mengíbar, M., \& Heras, M. (2011). Chitosan nanoparticles and microspheres for the encapsulation of natural antioxidants extracted from Ilex paraguariensis. Carbohydrate Polymers, 84(2), 803-806. http://dx.doi.org/10.1016/j.carbpol.2010.07.003.

57. Li, X., Shi, X., Wang, M., \& Du, Y. (2011). Xylan chitosan conjugate: a potential food preservative. Food Chemistry, 126(2), 520-525. http://dx.doi.org/10.1016/j.foodchem.2010.11.037. PMid:25212164.

58. Batista, A. C. L., Villanueva, E. R., Amorim, R. V. S., Tavares, M. T., \& Campos-Takaki, G. M. (2011). Chromium (VI) ion 
adsorption features of chitosan film and its chitosan/zeolite conjugate 13X film. Molecules (Basel, Switzerland), 16(5), 3569-3579. http://dx.doi.org/10.3390/molecules16053569. PMid:21527884.

59. Yu, T., Yu, C., Chen, F., Sheng, K., Zhou, T., Zunun, M., Abudu, O., Yang, S., \& Zheng, X. (2012). Integrated control of blue mold in pear fruit by combined application of chitosan, a biocontrol yeast and calcium chloride. Postharvest Biology and Technology, 69, 49-53. http://dx.doi.org/10.1016/j. postharvbio.2012.02.007.

60. Moussa, S. H., Tayel, A. A., \& Al-Turki, I. A. (2013). Evaluation of fungal chitosan as a biocontrol and antibacterial agent using fluorescence-labeling. International Journal of Biological Macromolecules, 54, 204-208. http://dx.doi.org/10.1016/j. ijbiomac.2012.12.029. PMid:23270832.

61. Paiva, W. S., Souza, F. E., No., \& Batista, A. C. L. (2014). Avaliação da atividade antibacteriana da quitosana fúngica. Perspectivas Online: Biológicas e Saúde, 13, 37-43. Retrieved in 2016, July 15, from http://www.seer.perspectivasonline. com.br/index.php/biologicas e saude/article/view/495/442

62. Oliveira, C. E. V., Magnani, M., Sales, C. V., Pontes, A. L. S., Campos-Takaki, G. M., Stamford, T. C. M., \& Souza, E. L. (2014). Effects of chitosan from Cunninghamella elegans on virulence of post-harvest pathogenic fungi in table grapes (Vitis labrusca L.). International Journal of Food Microbiology, 171, 54-61. http://dx.doi.org/10.1016/j.ijfoodmicro.2013.11.006. PMid:24321603.

63. Tayel, A. A., Ibrahim, S. I. A., Al-Saman, M. A., \& Moussa, S. H. (2014). Fungal chitosan from date wastes and its application as a biopreservative for minced meat. International Journal of Biological Macromolecules, 69, 471-475. http://dx.doi. org/10.1016/j.ijbiomac.2014.05.072. PMid:24942991.

64. Taillandier, P., Joannis-Cassan, C., Jentzer, J. B., Gautier, C. S. N., Sieczkowski, N., Granes, D., \& Brandam, C. (2015). Effect of a fungal chitosan preparation on Brettanomyces bruxellensis, a wine contaminant. Journal of Applied Microbiology, 118(1), 123-131. http://dx.doi.org/10.1111/jam.12682. PMid:25363885.

65. Souza, F. E., No., Silva, H. C. A., Paiva, W. S., Torres, T. M., Rocha, A. C. P., Bezerra, A., \& Batista, A. C. L. (2017). Quitosana fúngica sobre larvas de nematoides gastrintestinais de caprinos. Arquivos do Instituto Biológico, 84(0), 1-5. http:// dx.doi.org/10.1590/1808-1657000542015.

66. Kitozyme. (2017, June 26). Belgium. Retrieved in 2016, July 15, from http://kitozyme.com/eng/innovation/technologieswith-non-animal-chitosan-and-chitin-glucan/kionutrime-csg

67. InvivoGen. (2017, June 26). San Diego. Retrieved in 2016, July 15 , from http://www.invivogen.com/chitosan-vaccigrade

68. Inbiose. (2017, June 26). Belgium. Retrieved in 2016, July 15, from http://inbiose.com/products.html

69. Franco, L. O., Stamford, T. C. M., Stamford, N. P., \& CamposTakaki, G. M. (2005). Cunningamella elegans (IFM 46109) como fonte de quitina e quitosana. Reviews in Analgesia, 14, 40-44. Retrieved in 2016, July 15, from http://www.scielo.cl/ scielo.php?script $=$ sci_nlinks\&ref $=2120900 \&$ pid $=$ S0717345 $8200700010000600009 \& \operatorname{lng}=\mathrm{es}$

70. Stamford, T. C. M., Stamford, T. L. M., Stamford, N. P., Barros, B., No., \& Campos-Takaki, G. M. (2007). Growth of Cunninghamella elegans UCP 542 and production of chitin and chitosan using yam bean medium. Electronic Journal of Biotechnology, 10(1), 1-6. http://dx.doi.org/10.2225/vol10issue 5-fulltext-1.

71. Fai, A. E. C., Stamford, T. C. M., \& Stamford, T. L. M. (2008). Potencial biotecnológico de quitosana em sistemas de conservação de alimentos. Revista Iberoamericana de Polímeros, 9(5), 435-451. Retrieved in 2016, July 15, from http://www.ehu.eus/reviberpol/pdf/JUL08/fai.pdf
72. Bento, R. A., Stamford, T. L. M., Campos-Takaki, G. M., Stamford, T. C. M., \& Souza, E. L. (2009a). Potential of chitosan from Mucor rouxxi UCP064 as alternative natural compound to inhibit Listeria monocytogenes. Brazilian Journal of Microbiology, 40(3), 583-589. http://dx.doi.org/10.1590/ S1517-83822009000300022. PMid:24031403.

73. Bento, R. A., Souza, E. L., Stamford, T. L. M., \& Stamford, T. C. M. (2009b). Perspectiva e potencial aplicação de quitosana como inibidor de Listeria monocytogenes em produtos cárneos. Revista Iberoamericana de Polimeros, 10(5), 260-274. Retrieved in 2016, July 15, from http://www.ehu.eus/reviberpol/pdf/ SEP09/bento.pdf

74. Batista, A. C. L., Silva, M. C. F., Batista, J. B., Nascimento, A. E., \& Campos-Takaki, G. M. (2013). Eco-friendly chitosan production by Syncephalastrum racemosum and application to the removal of acid orange 7 (AO7) from wastewaters. Molecules, 18(7), 7646-7660. http://dx.doi.org/10.3390/ molecules18077646. PMid:23884118.

75. Freitas, L. S., Martins, E. S., \& Ferreira, O. S. (2014). Produção e caracterização parcial de $\alpha$-amilase de Syncephalastrum racemosum. Revista Brasileira de Biociências, 12(4), 226-232. Retrieved in 2016, July 15, from http://www.ufrgs.br/seerbio/ ojs/index.php/rbb/article/view/3120

76. Cardoso, A., Lins, C. I. M., Santos, E. R., Silva, M. C. F., \& Campos-Takaki, G. M. (2012). Microbial enhance of chitosan production by Rhizopus arrhizus using agroindustrial substrates. Molecules, 17(5), 4904-4914. http://dx.doi.org/10.3390/ molecules 17054904. PMid:22543505.

77. Berger, L. R. R., Stamford, T. C. M., Stamford-Arnaud, T. M., Alcântara, S. R. C., Silva, A. C., Silva, A. M., Nascimento, A. E., \& Campos-Takaki, G. M. (2014). Green conversion of agroindustrial wastes into chitin and chitosan by Rhizopus arrhizus and Cunninghamella elegans strains. International Journal of Molecular Sciences, 15(5), 9082-9102. http://dx.doi. org/10.3390/ijms15059082. PMid:24853288.

78. Paiva, W. S., Souza, F. E., No., \& Batista, A. C. L. (2017). Characterization of polymeric biomaterial chitosan extracted from Rhizopus stolonifer. Journal of Polymer Materials, 34(1), 115-121. Retrieved in 2016, July 15, from https://search. proquest.com/openview/80a89aa7245f255dd08dd6497c2ae 7af $/ 1$ ?pq-origsite $=$ gscholar\&cbl $=506337$

79. Bento, A. R., Stamford, T. L. M., Stamford, T. C. M., Andrade, S. A. C., \& Souza, E. L. (2011). Sensory evaluation and inhibition of Listeria monocytogenes in bovine pâté added of chitosan from Mucor rouxii. Lebensmittel-Wissenschaft + Technologie, 44(2), 588-591. http://dx.doi.org/10.1016/j.lwt.2010.08.016.

80. Fai, A. E. C., Stamford, T. C. M., Stamford-Arnaud, T. M., Santa-Cruz, P. D. A., Silva, M. C. F., Campos-Takaki, G. M., \& Stamford, T. L. M. (2011). Physico-chemical characteristics and functional properties of chitin and chitosan produced by Mucor circinelloides using yam bean as substrate. Molecules, 16(8), 7143-7154. http://dx.doi.org/10.3390/molecules 16087143 . PMid:21862956.

81. Souza, E. L., Sales, C. V., Oliveira, C. E. V., Lopes, L. A. A., Conceição, M. L., Berger, L. R. R., \& Stamford, T. C. M. (2015). Efficacy of acoating composed of chitosan from Mucor circinelloides and carvacrol to control Aspergillus flavus and the quality of cherry tomato fruits. Frontiers in Microbiology, 6, 732. http://dx.doi.org/10.3389/fmicb.2015.00732. PMid:26257717.

82. Berger, L. R. R., Stamford, N. P., Willadino, L. G., Laranjeira, D., Lima, M. A. B., Malheiros, S. M. M., Oliveira, W. J., \& Stamford, T. C. M. (2016). Cowpea resistance induced against Fusarium oxysporum f. sp. tracheiphilum by crustaceous chitosan and by biomass and chitosan obtained from Cunninghamella elegans. Biological Control, 92, 45-54. http://dx.doi.org/10.1016/j. biocontrol.2015.09.006. 
83. Campos-Takaki, G. M. (2005). The fungal versatility on the copolymers chitin and chitosan production. In P. K. Dutta (Ed.), Chitin and chitosan opportunities and challenges (pp. 69-94). India: Dubey Printers and Graphics.

84. White, S. A., Farina, P. R., \& Fulton, I. (1979). Production and isolation of chitosan from Mucor rouxii. Applied and Environmental Microbiology, 38(2), 323-328. PMid:518086.

85. Crestini, C., Kovac, B., \& Giovannozzi-Sermanni, G. (1996). Production and isolation of chitosan by submerged and solidstate fermentation from Lentinus edodes. Biotechnology and Bioengineering, 50(2), 207-210. http://dx.doi.org/10.1002/ bit.260500202. PMid:18626937.

86. Rane, K. D., \& Hoover, D. G. (1993). Production of chitosan by fungi. Food Biotechnology, 7(1), 11-33. http://dx.doi. org/10.1080/08905439309549843.

87. Hu, K. J., Yeung, K. W., Ho, K. P., \& Hu, J. L. (1999). Rapid extraction of high-quality chitosan from mycelia of Absidia glauca. Journal of Food Biochemistry, 23(2), 187-196. http:// dx.doi.org/10.1111/j.1745-4514.1999.tb00013.x.

88. Batista, A. C. L., Bandeira, M. G. L., Souza, F. E., No., Paiva, W. S., Rodrigues, D. N. R., \& Costa, A. C. A. A. (2014). Obtenção de quitosana fúngica crescida em meio alternativo constituído com farinha de carapaça de camarão. Revista Saúde e Ciência On Line, 3(3), 11-17. Retrieved in 2016, July 15, from http://www.ufcg.edu.br/revistasaudeeciencia/index.php/ RSC-UFCG/article/view/246

89. Bessa-Junior, A. P., \& Gonçalves, A. A. (2013). Análises econômica e produtiva da quitosana extraída do exoesqueleto de camarão. Acta Of Fisheries and Aquatic Resources, 1(1), 13-28. Retrieved in 2016, July 15, from http://www.seer.ufs. br/index.php/ActaFish/article/view/1589/1488

90. Berger, L. R. R., Stamford, T. C. M., Stamford-Arnaud, T. M., Franco, L. O., Nascimento, A. E., Cavalcante, H. M. M., Macedo, R. O., \& Campos-Takaki, G. M. (2014). Effect of corn steep liquor (CSL) and cassava wastewater $(\mathrm{CW})$ on chitin and chitosan production by Cunninghamella elegans and their physicochemical characteristics and cytotoxicity. Molecules, 19(3), 2771-2792. http://dx.doi.org/10.3390/ molecules19032771. PMid:24590203.

91. Neves, A. C., Schaffner, R. A., Kugelmeier, C. L., Wiest, A. M., \& Arantes, M. K. (2013). Otimização de processos de obtenção de quitosana a partir de resíduo da carcinicultura para aplicações ambientais. Revista Brasileira de Energias Renováveis, 2(1), 34-47. http://dx.doi.org/10.5380/rber. v2i1.33800.

92. Jaworska, M. M., \& Konieczna, E. (2001). The influence of supplemental components in nutrient medium on chitosan formation by the fungus Absidia orchidis. Applied Microbiology and Biotechnology, 56(1-2), 220-224. http://dx.doi.org/10.1007/ s002530000591. PMid:11499934.

93. Tanaka, H. (2001). Scale-up for fermentative production. Japão: Kyoritu Shuppan.
94. Chatterjee, S., Adhya, M., Guha, A. K., \& Chatterjee, B. P. (2005). Chitosan from Mucor rouxii: production and physicochemical characterization. Process Biochemistry, 40(1), 395 400. http://dx.doi.org/10.1016/j.procbio.2004.01.025.

95. Chatterjee, S., Chatterjee, S., Chatterjee, B. P., \& Guha, A. K. (2008). Enhancement of growth and chitosan production by Rhizopus oryzae in whey medium by plant growth hormones. International Journal of Biological Macromolecules, 42(2), 120-126. http://dx.doi.org/10.1016/j.ijbiomac.2007.10.006. PMid:18023862.

96. Martínez-Camacho,A. P., Cortez-Rocha, M. O., Ezquerra-Brauer, J. M., Graciano-Verdugo, A. Z., Rodriguez-Félix, F., CastilloOrtega, M. M., Yépiz-Gómez, M. S., \& Plascencia-Jatomea, M. (2010). Chitosan composite films: Thermal, structural, mechanical and antifungal properties. Carbohydrate Polymers, 82(2), 305-315. http://dx.doi.org/10.1016/j.carbpol.2010.04.069.

97. Khan, T. A., Peh, K. K., \& Ch'ng, H. S. (2002). Reporting degree of deacetylation values of chitosan: the influence of analytical methods. Journal of Pharmacy \& Pharmaceutical Sciences, 5(3), 205-212. PMid:12553887.

98. Rinaudo, M., Milas, M., \& Dung, P. L. (1993). Characterization of chitosan. Influence of ionic strength and degree of acetylation on chain expansion. International Journal of Biomacromolecules, 15(5), 281-285. http://dx.doi.org/10.1016/0141-8130(93)90027-J. PMid:8251442.

99. Stamford, N. P., Santos, C. E. R. S., Stamford, T. C. M., Franco, L. C., \& Arnaud, T. M. S. (2015). BR 102013003043 0. Rio de Janeiro: INPI. Retrieved in 2016, July 15, from https://gru. inpi.gov.br/pePI/servlet/PatenteServletController?Action=de tail\&CodPedido $=987310 \&$ SearchParameter $=$ BIOFERTILIZ ANTE $\% 20 \% 20 \% 20 \% 20 \% 20 \% 20 \&$ Resumo $=\&$ Titulo=

100.Chien, R., Yen, M., \& Mau, J. (2016). Antimicrobial and antitumor activities of chitosan from shiitak estipes, compared to commercial chitosan from crab shells. Carbohydrate Polymers, 138(1), 259-264. http://dx.doi.org/10.1016/j. carbpol.2015.11.061. PMid:26794761.

101.Tayel, A. A. (2016). Microbial chitosan as a biopreservative for fish sausages. International Journal of Biological Macromolecules, 93(1), 41-46. http://dx.doi.org/10.1016/j. ijbiomac.2016.08.061. PMid:27565293.

102.Tayel, A. A., El-Tras, W. F., \& Elguindy, N. M. (2016). The potentiality of cross-linked fungal chitosan to control watercontamination through bioactive filtration. International Journal of Biological Macromolecules, 88(1), 59-65. http:// dx.doi.org/10.1016/j.ijbiomac.2016.03.018. PMid:26995612.

Received: July 15, 2016

Revised: Aug. 22, 2017

Accepted: Oct. 10, 2017 